\title{
DESIGN OF A MUSEUM AND ART GALLERY IN YOGYAKARTA WITH A NEO VERNACULAR ARCHITECTURAL APPROACHPERANCANGAN MUSEUM DAN GALERI SENI RUPA DI YOGYAKARTA DENGAN PENDEKATAN ARSITEKTUR NEO VERNAKULAR
}

\author{
Galih Tri Kurniadi $^{1)}$, Mutiawati Mandaka ${ }^{2}$, Carina Sarasati ${ }^{3)}$ \\ Program Studi Arsitektur, Fakultas Teknik, Universitas Pandanaran \\ piranti.print@gmail.com ${ }^{1)}$ \\ mutiawatimandaka@gmail.com ${ }^{2)}$ \\ carinasarasati@gmail.com ${ }^{3)}$
}

\begin{abstract}
Abstrak
Melalui predikat kota cagar budaya dan pariwisata, Yogyakarta memiliki potensi yang sangat besar untuk berkembang diantaranya melalui Seni. Dikenal memiliki banyak kebudayaan dan kesenian salah satunya seni rupa. Yogyakarta menghasilkan seniman besar seni rupa yaitu Nasirun, Heri Dono, Bagong Kusdiarjo dan masih banyak lagi. Sebagai kota dengan tingkat budaya dan seni yang tinggi tentunya Yogyakarta mempunyai banyak sekali Museum dan Galeri Seni sebagai praktik pameran dan diskusi. Beberapa Museum dan Galeri Seni di Yogyakarta yang terkenal antara lain Museum Ullen Sentallu, Museum Sonobudoyo, Galleri Affandy dan Galleri Cemety. Banyaknya kegiatan, event dan Pasti artis yang sedang berkembang di Yogyakarta.Hal ini sebagai latar belakang perancangan pembangunan museum dan galeri seni rupa baru di Yogyakarta. Sehingga dapat menjadikan tempat sebagai perantara antara karya seni dari seniman ke penikmat atau pengunjung.

Kata kunci : Yogyakarta, Museum, Galeri Seni, Seni Rupa, Budaya
\end{abstract}

\begin{abstract}
Through the title of a city of cultural heritage and tourism, Yogyakarta has enormous potential to develop, among others, through art. It is known to have many cultures and arts, one of which is fine art. Yogyakarta produces major fine arts artists, namely Nasirun, Heri Dono, Bagong Kusdiarjo, and many more. As a city with a high level of culture and art, of course Yogyakarta has many museums and art galleries as exhibition and discussion practices. Some of the famous museums and art galleries in Yogyakarta include Ullen Sentallu Museum, Sonobudoyo Museum, Affandy Gallery and Cemety Gallery. There are many activities, events and artists in Yogyakarta that will certainly continue to develop. This is the background for the design of a new art gallery and development museum in Yogyakarta. So that it can make a place as an intermediary between artwork from artists to connoisseurs or visitors.
\end{abstract}

Keywords : Yogyakarta, Museums, Art Galleres, Fine Arts, Culture 


\section{PENDAHULUAN}

Yogyakarta dikenal sebagai salah satu situs warisan budaya Jawa dengan potensi pengembangan yang besar. Yogyakarta dikenal sebagai rumah bagi banyak budaya dan seni, salah satunya adalah seni. Ada banyak seniman besar di Yogyakarta, seperti Nasirun, Heri Dono dan Bagong Kusdiarjo. Ia telah memberikan kontribusi yang signifikan bagi pertumbuhan praktik seni rupa Yogyakarta. Status sosial budaya Yogyakarta yang unik dipandang sebagai faktor utama sebagai kota yang berbasis seni dan kebudayaan. Yogyakarta, seperti halnya museum dan galeri yang telah ada sejak tahun 1990-an, adalah tempat lain yang telah melakukan cukup banyak untuk menciptakan iklim dan dinamisme artistik yang benar-benar menakjubkan. Di sisi lain, seniman dan seniman yang tidak lahir di Yogyakarta tetapi memilih untuk tinggal di Yogyakarta merupakan aset penting yang dapat meningkatkan kemasyhuran seni rupa yang kekurangan ruang di rumahnya sendiri, demikian pula kegiatan seninya. dan ruang untuk mereka. Hal ini sebagai latar belakang perancangan pembangunan museum dan galeri seni rupa baru di Yogyakarta. Sehingga dapat menjadikan tempat sebagai perantara antara karya seni dari seniman ke penikmat atau pengunjung. Juga untuk daftar jumlah museum dan galeri seni Jogjakarta sebagai kota pariwata dan budaya.

\section{TINJAUAN TEORI}

Konsep bangunan museum dan seni yang digunakan yaitu pendekatan arsitektur neo-vernakular yang diaplikasikan pada desain bangunan museum dan galeri seni. Selanjutnya, penerapan arsitektur angiogenik adalah elemen arsitektur yang sudah ada baik secara fisik (formal, struktural) maupun tidak secara fisik (konsep, filosofi, tata ruang).

\section{METODOLOGI PERANCANGAN}

- Pendekatan Pelaku Kegiatan

Pembagian kelompok pelaku kegiatan yang berdasarkan pada tujuan yang sama yaitu menikmati karya seni. Yang mana masingmasing pembagian kelompok sangat berpengaruh terhadap perencanaan dan perancangan museum dan galeri seni.

- Pendekatan Aspek Teknis Melingkupi analisa struktur dan kontruksi, karakteristik pada ruangruang, persyaratan sifat pada masing-masing ruang yang ada dan analisa tema yang digunakan terhadap eksterior dan interior.

- Pendekatan Aspek Konstektual

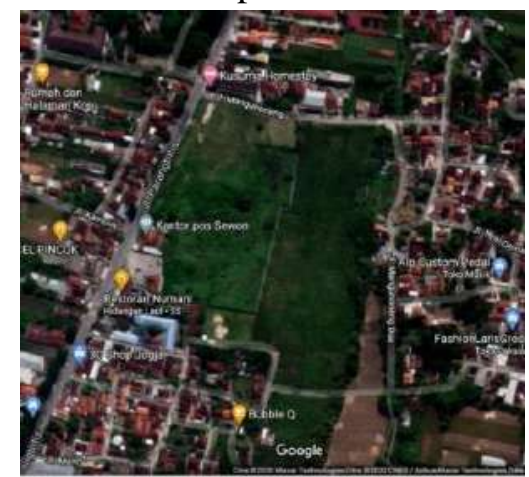

Gambar 1, Pemilihan Lokasi Terpilih

Lokasi terpilih berada di Jl. Prangtritis, Sewon, Bantul DIY berorientasi ke barat dan merespon kedalam site. Adapun batasan tapak sebagai berikut:

Timur : Pemukiman warga

Utara : hotel / Penginapan

Selatan : Pertokoan dan Kantor

Barat : Jl.Parangtritis / Jl. Utama 


$\begin{array}{ll}\text { Luas Total Bangunan } & : 36.397 \mathrm{~m}^{2} \\ \text { Luas Lahan } & : 72.732 \mathrm{~m}^{2} \\ \text { KDB 60\% } & : 43.639 \mathrm{~m}^{2} \\ \text { KLB } & : 5 \text { Lantai } \\ \text { GSB } & : 6 \mathrm{~m} \\ \text { KDH } & : 29.029 \mathrm{~m}^{2}\end{array}$

A. Analisa Orientasi Matahari

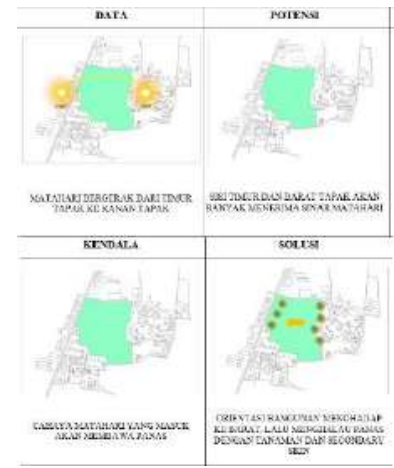

Gambar 2 Analisa Orientasi Matahari

B. Analisa Arah Angin

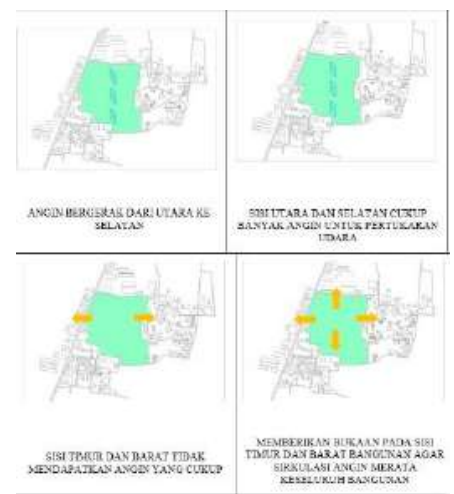

Gambar 3. Analisa Arah Mata Angin

C. Analisa Orientasi Tapak
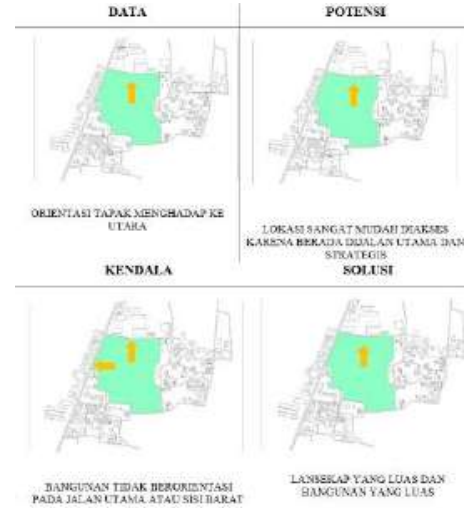

Gambar 4. Analisa Orientasi Tapak

D. Analisa Kebisingan
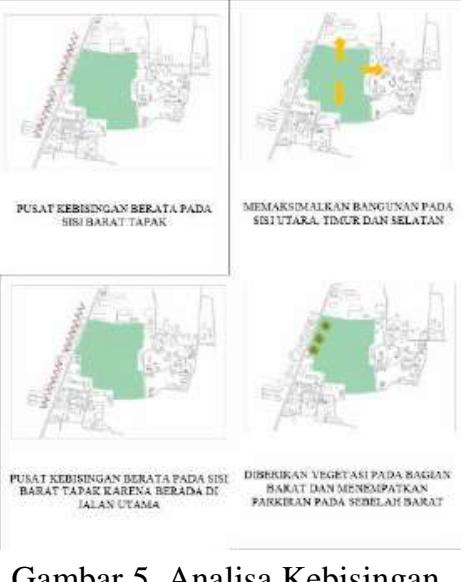

Gambar 5. Analisa Kebisingan

E. Analisa View

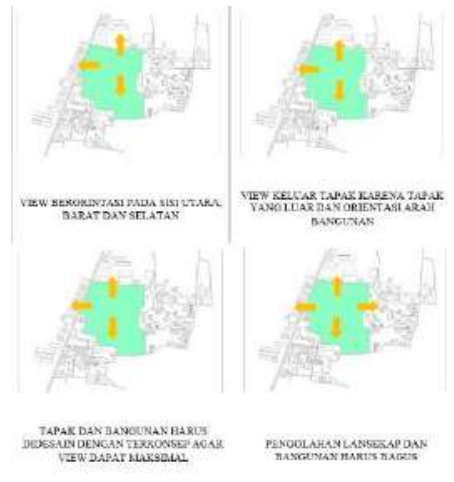

Gambar 6. Analisa View

F. Analisa Vegetasi 


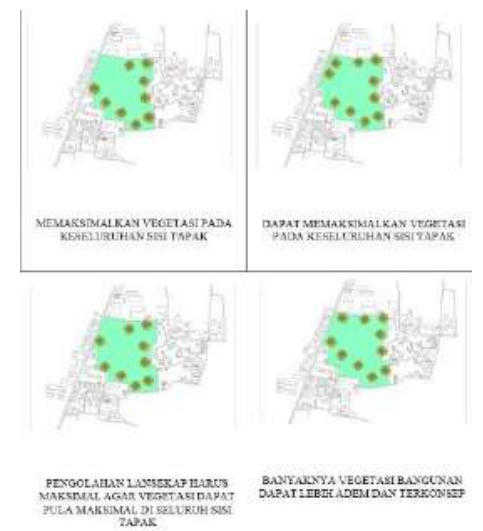

Gambar 7. Analisa Vegetasi

\section{G. Aksebilitas}

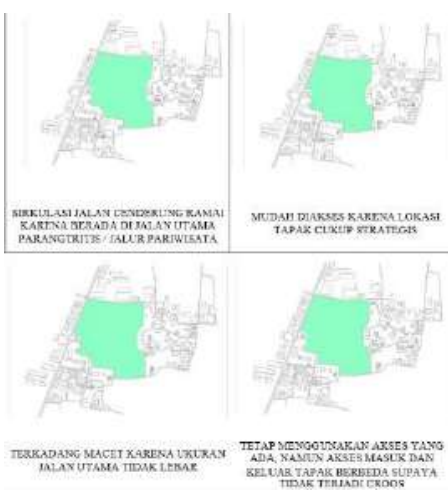

Gambar 8. Analisa Aksebilitas

\section{H. Drainase}

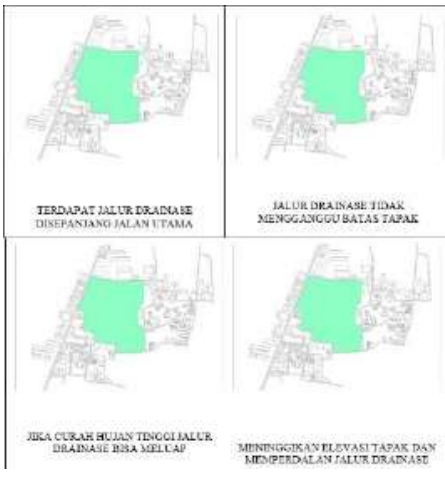

Gambar 9. Analisa Drainase

- Pendekatan Apek Fungsional

A. Program Aktivitas Pelaku

- Kelompok Pengunjung

- Kelompok Pengelola

\section{B. Program Kebutuhan Ruang}

Tabel 3.1 Kebutuhan Ruang

\begin{tabular}{|c|c|c|c|c|c|}
\hline $\mathrm{No}_{0}$ & Nima Rumg & Sumber & Stanis & Kapuíta & Toal Luarume? \\
\hline 1 & Hall Lobby & NAD & $15 \mathrm{sm} 2 \mathrm{arg}$ & 500 ang & 730 \\
\hline$T$ & Loket & NAD & $15 \mathrm{~m}^{2} \mathrm{org}$ & 100 orf & 150 \\
\hline 2 & Reurg thifomali & NWD & $\mathrm{LSm}^{2} \mathrm{org}$ & 10 oxt & 15 \\
\hline 3 & Puratipan Bxaly & NQ10 & Im2 orf & $50 \mathrm{og}$ & 50 \\
\hline 4 & RPimier Ters & Nat & $5 \mathrm{~m}^{2} \mathrm{arg}$ & 500 ore & 2500 \\
\hline 3 & RPEme Tespore & WaO & $\begin{array}{l}\text { SOE } \\
\text { RP Thas }\end{array}$ & $500 \times 8$ & 2000 \\
\hline 6 & R. Seninx & NAD & $15 \mathrm{~m} 2 \mathrm{arg}$ & $300 \propto \mathrm{g}$ & 430 \\
\hline$?$ & R. Foratian & Now & $15 \mathrm{~m}^{2} \mathrm{org}$ & $300 \mathrm{cog}$ & 456 \\
\hline 8 & Toulst & NaD & $13 \mathrm{~m} 2 \mathrm{org}$ & 10 orf & 13 \\
\hline 9 & Amphisate & PS & $15 \mathrm{ml}$ ort & $50000 \mathrm{~g}$ & 730 \\
\hline 10 & Parpustakane & PS & $15 \mathrm{mang}$ & 100 as: & 150 \\
\hline II & Toko Sounenit & PS & 13 mbats & 100 ang & 130 \\
\hline \multicolumn{3}{|c|}{ Taming } & \multicolumn{3}{|r|}{$6,400 \mathrm{~m}^{2}$} \\
\hline \multirow{2}{*}{\multicolumn{3}{|c|}{ FHow $40 \%$}} & \multicolumn{3}{|r|}{$2,575 \mathrm{~m}^{2}$} \\
\hline & & JumlitTonl & \multicolumn{3}{|r|}{$9,005 \mathrm{~m}$} \\
\hline
\end{tabular}

\begin{tabular}{|c|c|c|c|c|c|}
\hline$N_{0}$ & Nama Bexeg & Sumber & $\operatorname{standx}$ & Kapuiza & Tood Laves m? \\
\hline 1 & R. Tami & NAD & $3 \log x$ & $100 \mathrm{cos}$ & 30 \\
\hline $2^{2}$ & 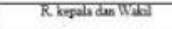 & NaD & प्राजe & 2बा & 6 \\
\hline 3 & R Rapat & NAD & Imang & $30 \mathrm{crz}$ & 60 \\
\hline 4 & 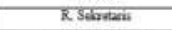 & NaD & उल्का बह & ग्यु & 9 \\
\hline 5 & 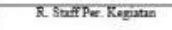 & KaD & Inimicog & 10 arg & 30 \\
\hline 6 & 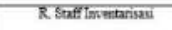 & NAD & 3mict & 4 ore & 12 \\
\hline T & R. Starifop Hania & Now & $3 \mathrm{sin} / \mathrm{cos}$ & Sart & 12 \\
\hline 8 & 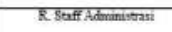 & NAD & $3 m$. of & 2ब्ह & 6 \\
\hline 9 & $\overline{R c h a m a n g}$ & 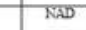 & $3 \ln 6 \mathrm{cos}_{\mathrm{g}}$ & $100 \mathrm{ag}$ & 30 \\
\hline 10 & R Kuratir & NAD & Aminger & उors & 20 \\
\hline 11 & 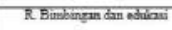 & $\mathrm{N} A \mathrm{~S}$ & Sim $\cos$ & 10 org & 30 \\
\hline 12 & R attratare Steaf & NWW & 3miceng & $10 \mathrm{org}$ & 30 \\
\hline 13 & 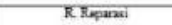 & NaD & 3ning & $200 \mathrm{Bg}$ & 80 \\
\hline 114 & KR Remenari: & NWD & 3mang & S0 orf & 130 \\
\hline 15 & R.Panj imparan Kolekii & $N=D$ & $3 \mathrm{sin} / \mathrm{con}$ & $50 \mathrm{cos}$ & 150 \\
\hline 15 & Pantri & NAD & Im org & $10 \mathrm{org}$ & 30 \\
\hline 16 & Toile & NAD & $1.5 \mathrm{~m}$ org & $15 \times \mathrm{gz}$ & 223 \\
\hline 17 & Gdant & Nats & 15m or & $20 \mathrm{og}$ & 30 \\
\hline Tomata & & & & & $3015 \mathrm{~m}^{2}$ \\
\hline$+\mathrm{HlOW}_{2} \mathrm{~s}$ & & & & & $615 \mathrm{~m}^{2}$ \\
\hline Tominh & & & & & $369 \mathrm{~m}^{2}$ \\
\hline No & Nama Barang & Sumber & Standar & Kapasitas & \begin{tabular}{|l|} 
Total \\
Luasan \\
$\mathrm{m} 2$
\end{tabular} \\
\hline 1 & Loading Dock & NAD & $30 \mathrm{~m} 2$ bus & 3 truk & 90 \\
\hline 2 & $\begin{array}{l}\text { R.Admin } \\
\text { Koleksi }\end{array}$ & NAD & $3 \mathrm{~m} / \mathrm{org}$ & 5 org & 15 \\
\hline 3 & $\begin{array}{l}\text { R. Penyimpanan } \\
\text { Sementara }\end{array}$ & NAD & $3 \mathrm{~m} / \mathrm{org}$ & 100 org & 300 \\
\hline 4 & R. Arsip Koleksi & NAD & $3 \mathrm{~m} /$ org & 100 org & 300 \\
\hline 5 & R. Kurator & NAD & $3 \mathrm{~m} / \mathrm{org}$ & 5 org & 15 \\
\hline \multicolumn{4}{|c|}{ Jumlah } & \multicolumn{2}{|r|}{$720 \mathrm{~m}^{2}$} \\
\hline \multicolumn{4}{|c|}{ +Flow $40 \%$} & \multicolumn{2}{|r|}{$288 \mathrm{~m} 2$} \\
\hline \multicolumn{4}{|c|}{ Jumlah Total } & \multicolumn{2}{|r|}{$1,008 \mathrm{~m} 2$} \\
\hline
\end{tabular}




\begin{tabular}{|c|l|c|c|c|c|}
\hline No & Nama Barang & Sumbe & Standar & Kapasitas & $\begin{array}{l}\text { Total } \\
\text { luasan } \\
\mathrm{m} 2\end{array}$ \\
\hline 1 & Parkir bus & AS & $30 \mathrm{~m} 2$ bus & 3 bus & 90 \\
\hline 2 & Parkir mobil & AS & $12,5 \mathrm{~m} 2 \mathrm{mbl}$ & 50 mobil & 625 \\
\hline 3 & Parkir motor & AS & $2 \mathrm{~m} 2 / \mathrm{mtr}$ & $100 \mathrm{mtr}$ & 200 \\
\hline 4 & $\begin{array}{l}\text { Parkir } \\
\text { Pengelola }\end{array}$ & AS & $12,5 \mathrm{~m} 2 \mathrm{mbl}$ & 25 mobil & 312,5 \\
\hline & & & $20 \mathrm{mtr}$ & 40 \\
\hline Jumlah & & $2 \mathrm{~m} 2 / \mathrm{mtr}$ & & $1,267.5 \mathrm{~m} 2$ \\
\hline
\end{tabular}

\begin{tabular}{|c|c|c|}
\hline No & Nama Bragining & Jumbah L,awen m? \\
\hline 1 & Bagian Penguajung & $9.005 \mathrm{~m}^{2}$ \\
\hline 2 & Bagian Administras & $360 \mathrm{~m}^{2}$ \\
\hline 3 & Baziinan Servis & $6076 \mathrm{mz}$ \\
\hline 4 & Besein Kolcke Barane Bullya & $1008 \mathrm{~m}^{2}$ \\
\hline 5 & Bagiant Lapagangan Paikiti & 1,2675 \\
\hline \multicolumn{2}{|l|}{ Jumlact } & 12,2575 \\
\hline \multicolumn{2}{|c|}{ Total Latan Tetangun } & 12.257 .5 \\
\hline
\end{tabular}

Luas Lahan = Luas Bangunan + Ruang Bangunan Hijau ( $40 \%$ Luas Lahan) \#Jadi total luas bangunan adalah $\mathbf{- 3 6 . 3 9 7}$

C. Program Sirkulasi dan Hubungan Ruang

- Sirkulasi Pengunjung

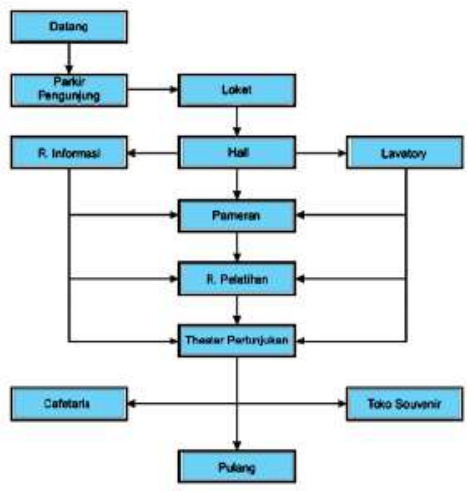

Diagram 1. Sirkulasi Pengunjung

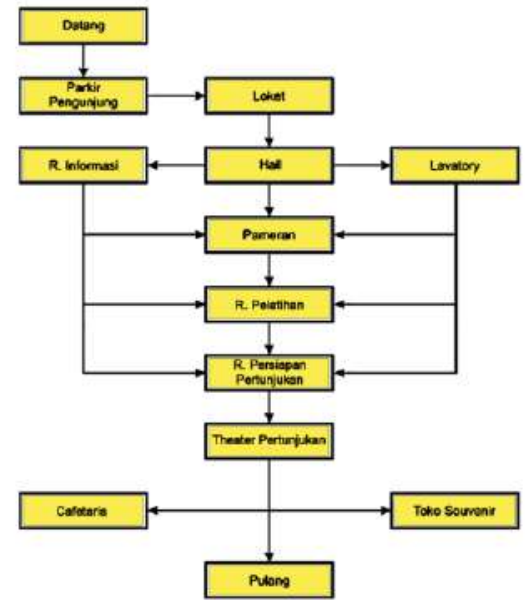

Diagram 2. Sirkulasi Pelaku Seni

- Sirkulasi Pengelola

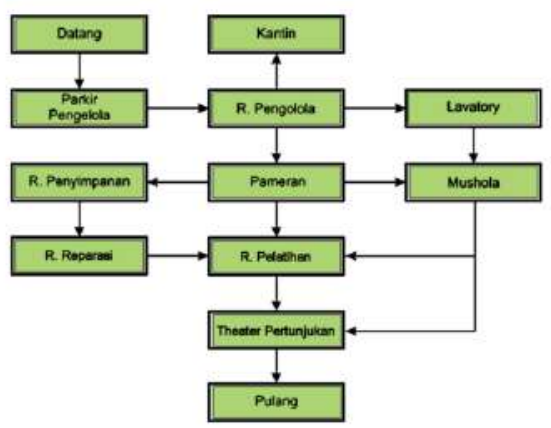

Diagram 3. Sirkulasi Pengelola

- Sirkulasi Barang Seni dan Budaya

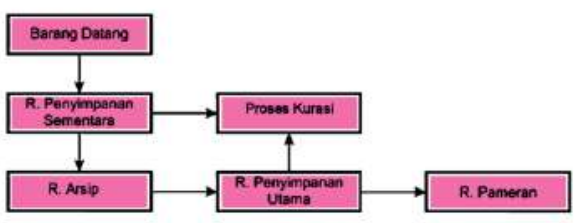

Diagram 4. Sirkulasi Barang Seni \& Budaya

D. Hubungan Pengelompokan Ruang

- Sirkulasi Pelaku Seni 


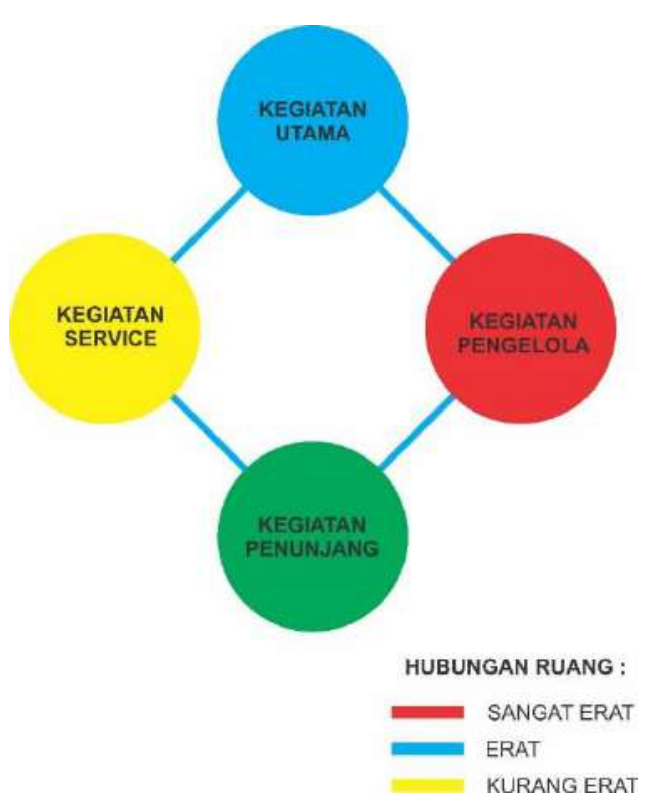

Diagram 5. Hubungan Pengelompokan Ruang

\section{PEMBAHASAN}

A. Konsep Tapak

1. Konsep Tata Letak

Perencanaan lokasi tapak dibuat untuk menanggapi analisa tapak pada pembahasan sebelumnya. Berdasarkan analisa maka tata letak bangunan akan berada di sebelah tengah menghadap ke barat

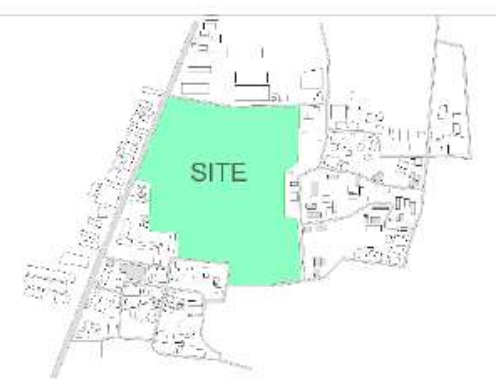

Gambar 10. Konsep Tapak

2. Konsep Pencapaian

- ME berada pada bagian yang lebih dekat dengan jalan utama. Agar pengunjung dapat dengan mudah mengakses lokasi museum dan galeri. petunjuk jalan diperlukan untuk mempermudah akses.

- Jalur untuk servis / karyawan dipisahkan, supaya kenyamanan pengunjung tidak terganggu oleh adanya kegiatan servis.

- Pemisahan antar kedua jalur tersebut untuk menghindari cross antar pengguna saat akan masuk atau keluar museum dan galeri.

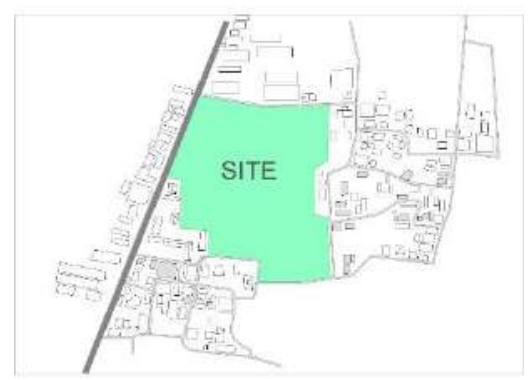

Gambar 11. Konsep Pencapaian

3. Konsep View

- Konsep view dari luar di dasarkan pada analisa view yang sudah ada. View dari luar harus dapat terlihat dari berbagai arah sehingga bangunan terlihat lebih menonjol.

- Untuk view dari site keluar memiliki orientasi ke arah barat, utara dan selatan. 


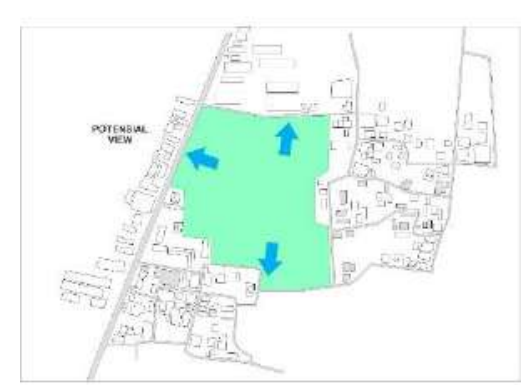

Gambar 12. Konsep View

4. Konsep Kebisingan

- Lokasi site yang dekat dengan jalan utama sehingga kebisingan dari kendaraan tinggi.

- Bangunan utama diposisikan di tengah sehingga kebisingan dari arah barat dapat diminimalisir.

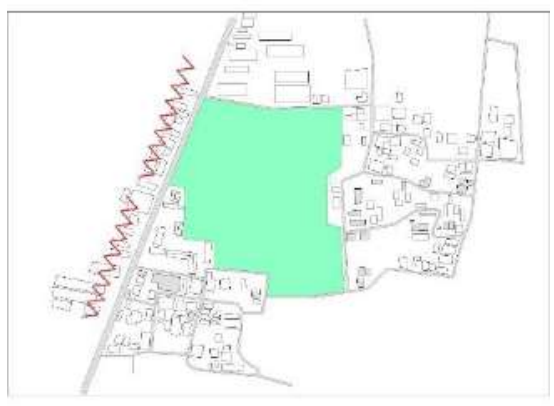

Gambar 13. Konsep Kebisingan

5. Konsep Pencahayaan

- Bukaan serta muka bangunan lebih banyak mengarah ke utara dan selatan. Bangunan yang menghadap ke arah barat menggunakan secondary skin dan diberi vegetasi.

- Intensitas matahari yang tinggi dapat dimanfaatkan untuk mengurangi penggunaan pencahayaan buatan.

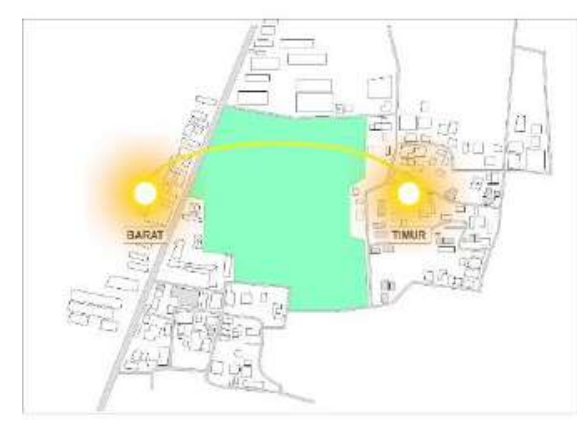

Gambar 14. Konsep Matahari

\section{Konsep Angin}

- Site berada di daerah laut sehingga hembusan angin laut cukup tinggi.

- Penggunaan bukaan yang banyak menjadikan sirkulasi angin masuk kedalam bangunan lebih banyak.

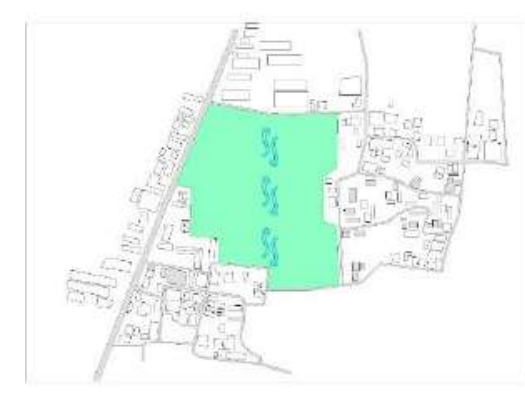

Gambar 15. Konsep Angin

7. Konsep Sirkulasi Kendaraan

- Sirkulasi kendaraan dapat terlihat pada gambar diatas dengan warna biru. Kendaraan masuk bisa menuju area parkir pengunjung. Untuk jalur kendaraan service atau 
penunjang memiliki pintu masuk yang sama.

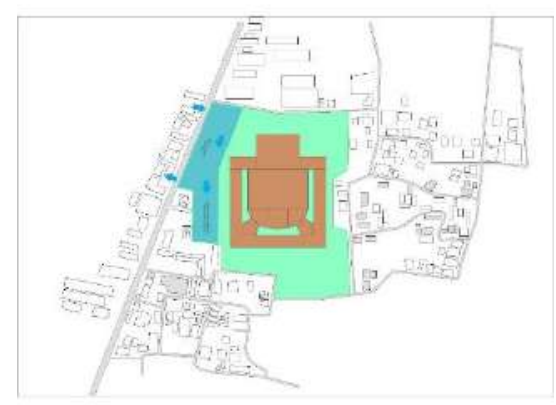

Gambar 16. Konsep Sirkulasi Kendaraan

8. Konsep Zoning

- Pemisahan antara zona publik, private dan service

- Zona publik berada dibagian paling dekat dengan pintu masuk site dan bangunan.

- Zona private berada pada bagian tengah bangunan

\section{B. Konsep Gubahan Massa}

\section{Bentuk Dasar}

Bentuk site ini seperti trapesium yang dimana di dalamnya terdapat beberapa zona ruang yang muncul dari aktivitas yang diwadahi. Bentuk dasar mengadopsi dari tata ruang bangunan rumah joglo.

\section{Kesan Ruang}

Kesan ruang yang ingin di capai pada bangunan meseum dan galeri seni ini adalah :

- Indera penglihatan. berfungsi untuk merespon material lantai, dinding, plafond, pencahayaan dan intensitas warna cahaya
- Indera pendengaran. Berfungsi untuk merespon audio visual

- Indera penciuman. Berfungsi untuk merespon material yang sebenarnya.

\section{Konsep Orientasi Bangunan}

Konsep view dari luar didasarkan pada analisa view yang sudah ada. View dari luar harus dapat terlihat dari berbagai arah sehingga bangunan dapat terlihat menonjol. Untuk view dari site keluar memiliki orientasi ke arah barat menghadap ke jalan utama

\section{Konsep Gubahan Massa}

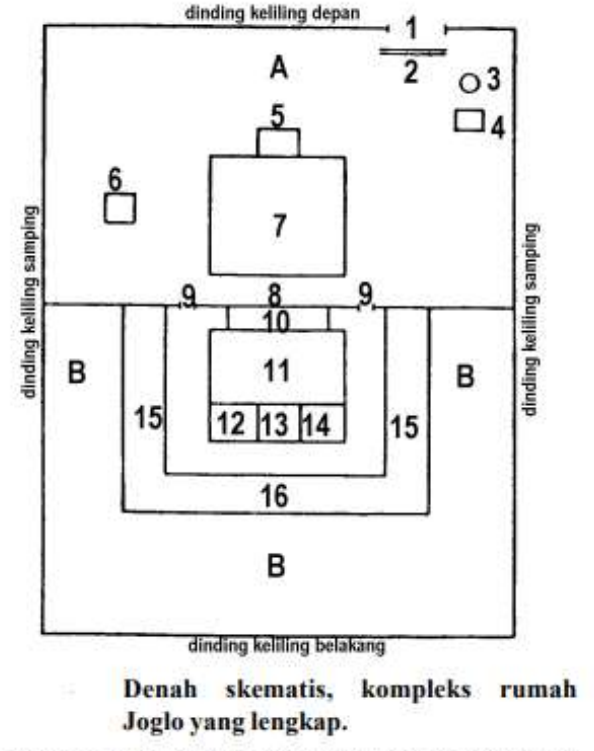

Legenda: 1.Regol. 2.Rana. 3.Sumur. 4.Langgar. 5.Kuncung 6.Kandang kuda. 7.Pendapa. 8.Longkonan. 9.Seketheng. 10.Pringgitan. 11.Dalem. 12.Senthong kiwa (kiri). 13. Sentong tengah (kanan). 14.Sentong kanan. 15.Ganchok 16. Dapur dan lain-lain A.Halaman luar. B.Halaman dalam.

Gambar 17. Konsep Gubahasan Massa

Gubahan massa bangunan merupakan konsep yang terdiri dari beberapa bentuk sehingga bangunan tidak terlihan motonon konsep perencanaan gubahan massa 
mengambil konsep tata ruang yang ada pada rumah joglo.

\section{Pendekatan Arsitektural}

- Arsitektur Neo vernacular adalah sebuah konsep dimana konsep prinsip mempertimbangkan prinsip normatif, alam semesta, peran budaya lokal.

- Nilai-nilai yang terkandung dalam setiap bentuk motif batik mewakili pesan dan harapan baik bagi pengguna maupun pawangnya. Seperti halnya batik kawung yang dihadirkan dalam bangunan ini salah satunya. Kawin silang antara hasrat yang mendalam pada seni budaya dan arsitektur untuk mewujudkan nilai / identitas budaya yang kuat, serta membangun kenangan yang tak hanya berdaya pikat, tappi juga simbolik dan mengikat ingatan manusia. Sejatinya makna filosofi dari motif kawung itu sangat dalam, yaitu: kesepurnaan, kesucian, kemurnian, Seperti pola geometris, mereka diyakini bermanfaat bagi orang lain di setiap langkah.

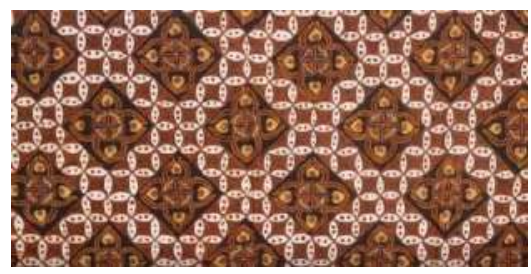

Gambar 18. Batik Kawung
- Bahwa identitas budaya disetiap daerah sangat penting untuk diaplikasikan dalam bangunan dan terutama pada konsep neo vernakular. Seperti pada contoh Pintu gerbang gapura ini terinspirasi dari gapura agung keraton yogyakarta. Bahwa yogyakarta tidak bisa lepas dengan adanya kaeraton sehingga dengan ada kraton kita selalu disadarkan untuk selalu melestarikan kebudayaan.

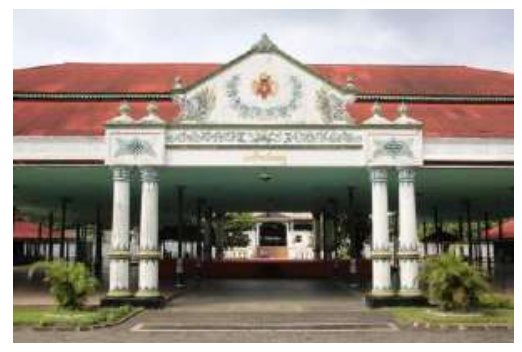

Gambar 19. Gapura Keraton

\section{Konsep Penghijauan}

Penghijauan tanaman berfungsi sebagai peneduh dan penyegar kondisi site. Juga dapat memfilter kebisingan sari polusi udara dan mengurangi arus angin. Konsep penghijauan dilakukan pada bagian :

- Lahan

Penghijauan pada lahan agar tercipta udara segar yang dihasilkan oleh pepohonan pada lingkungan sekitar massa bangunan dan juga membantu dalam pencapaian sirkulasi diluar bangunan. 


\section{- Bangunan}

Untuk mendukung konsep ecogreen, penghijauan juga dapat diberikan didalam bangunan maupun pada dinding bangunan.

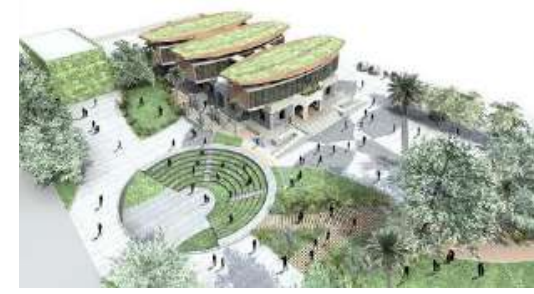

Gambar 20. Konsep Penghijauan

\section{Konsep Parkir}

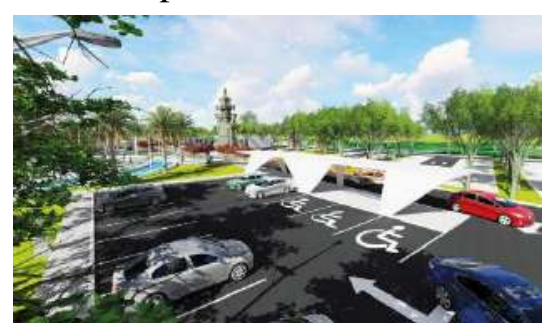

Gambar 21. Konsep Parkir

Area parkir kendaraan dibedakan dalam beberapa bagian antara lain, parkir kendaraan roda dua, roda empat, bus, serta pengelola dan karyawan.

\section{Konsep Visual Arsitektur}

Museum dan galeri seni berfungsi sebagai bangunan yang di pertunjukan untuk suatu kegiatan pameran karya seni rupa. Untuk mewujudkan konsep visudalbangunan, berikut ini adalah contoh studi yang menjadi tolak ukur untuk mencapai citra visual bangunan :
- Potensi lokasi terpilih dimaksimalkan dengan penataan bangunan yang baik

- Pendekatan arsitektur pada bangunan sebagai konsep

- Fungsi bangunan dan konteks lingkungan merupakan dasar dari penerapan tema bangunan.

- Detail pada bangunan diperhatikan sehingga dapat penumpang dapat menikmatinya.

- Melalui wujud bangunan sebagai pesan yang ingin disampaikan

- Ruang luar dan dalam tertata dengan penataan bangunan yang baik.

Berdasarkan poin tersebut, bangunan ini diharapkan dapat menampilkan visual arsitektur yang diharapkan sesuai dengan tema, fungsi dan lingkungan.

\section{Konsep Ruang}

A. Konsep Ruang Luar

- Drainase

- Lampu

- Perencanaan Lansekap

- Signage (papan informasi)

Taman berperan sebagai pemandu lalu lintas dan penahan dampak kebisingan akibat aktivitas kendaraan dari luar kawasan. Taman juga memberikan kesan artistik.

B. Konsep Ruang Dalam

- Pencahayaan

- Kulalitas Cahaya

- Cahaya Berdasarkan Konsep 


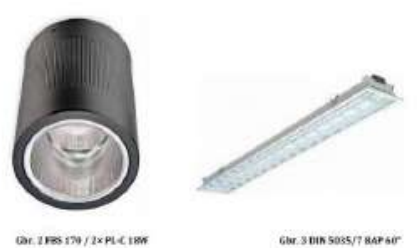

Gambar 22. Lampu Display

- Display

- Suhu dan Kelembapan

9. Konsep Struktur dan Kontruksi

A. Struktur Bawah

Dasar pemilihan sistem substruktur adalah kondisi tanah yang cenderung stabil. Lapisan bawah menggunakan lubang pondasi atau pancang mini. Pondasi ini digunakan untuk memotong bangunan tiga lantai. Pemilihan pondasi ini memungkinkan untuk meminimalisir letak bangunan.

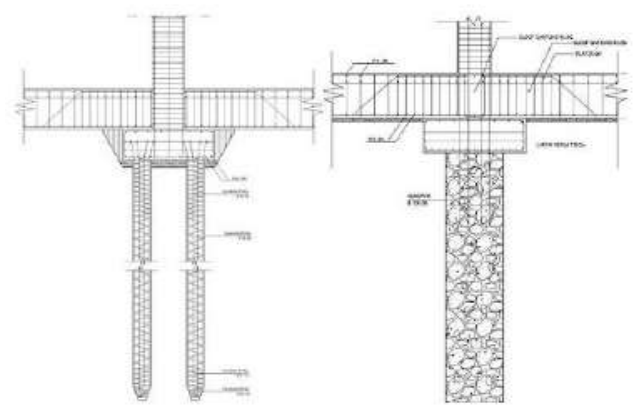

Gambar 23. Konsep struktur Bawah

\section{B. Struktur Tengah}

Struktur di bagian tengah sama dengan bentuk dinding bangunan. Struktur pusat terdiri dari kanopi, kolom, denah lantai dan balok. Desain bangunan museum dan galeri ini menggunakan beton bertulang dan struktur sentral.

- Sebagai peredam panas

- Anti air

- Peredam suara

- Dan sirkulasi udara masuk (dinding bernafas)

C. Struktur Atas

Pengertian cor beton di tempat adalah Komponen beton yang di cetak menjadi satu kesatuan ke dalam bangunan dan merupakan final akhir pada beton struktur. Cara penanganan campuran beton yaitu dimana lapisan pengecoran nya bentuk bangunan .metode ini dilakukan agar tidak terjadi sambungan dingin.

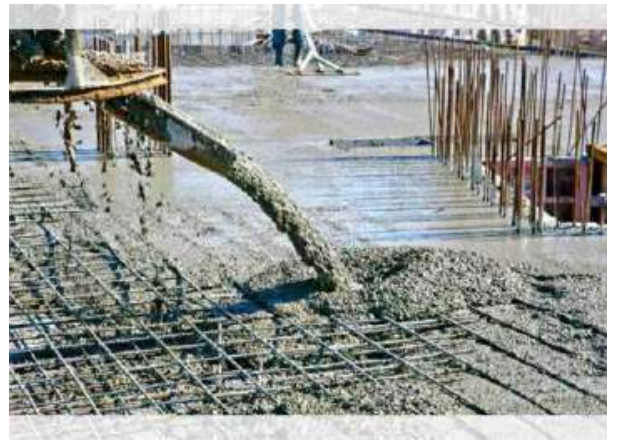

Gambar 24. Konsep struktur Atas

\section{Utilitas}

\section{A. Jaringan Air Bersih}

Sumber Sumber utama air bersih di gedung museum adalah sistem tangki bertekanan. Prinsip operasi dari sistem penyimpanan adalah memungkinkan air dalam wadah yang lebih rendah untuk dipompa ke tangki tertutup (tangki) dan 
udara terkompresi di dalam air di tangki untuk dipompa ke sistem distribusi bangunan.

B. Jaringan Air Kotor

- Grey Water

Air kotor ini berasal dari limbah cucian, kamar mandi, dan wastafel yang di tamping ke bak penampungan kemudian di filter. Hasil filteran ini diharapkan dapat digunakan Kembali untuk kebutuhan air di bangunan.

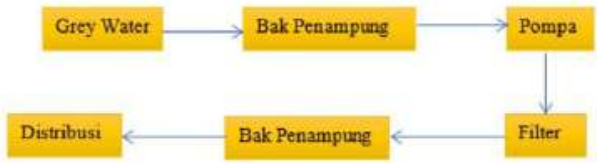

Diagram 6. Konsep Jaringan Air Kotor

- Black Water

Air limbah ini berasal dari kotoran manusia yang kemudian akan difiter dan dibuang di sumur resapan.

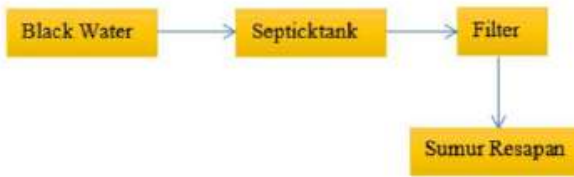

Diagram 7. Konsep Black Water

- Air Hujan

Air yg jatuh di area site dapat ditampung kemudian dimanfaatkan Kembali untuk memenuhi kebutuhan air pada bangunan.

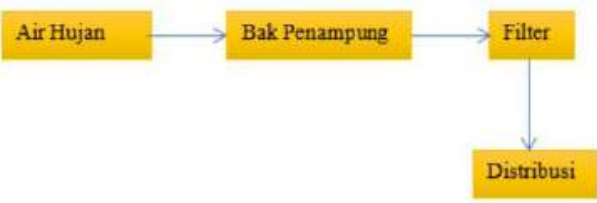

Diagram 8. Konsep Air Hujan

11.Sumber Listrik

Sumber listrik yang di gunakan pada perencanan Museum dan Galeri Seni bersumber dari listrik PLN dan juga Genset. Selain itu pada area parkir menggunkan energi listrik dari panel surya, yang prinsip penggunaanya yaitu mengubah sinar matahari menjadi energi listrik.

12. Sistem Kebakaran

- Apar

- Fire Hydrant Pilar

- Springkle

- Sensor Deteksi Asap

13. Sistem Keamanan

Untuk melengkapi sistem keamanan di atas, gedung dilengkapi dengan sistem pengawasan video. Pantau aktivitas semua pengguna kecuali aktivitas pribadi.

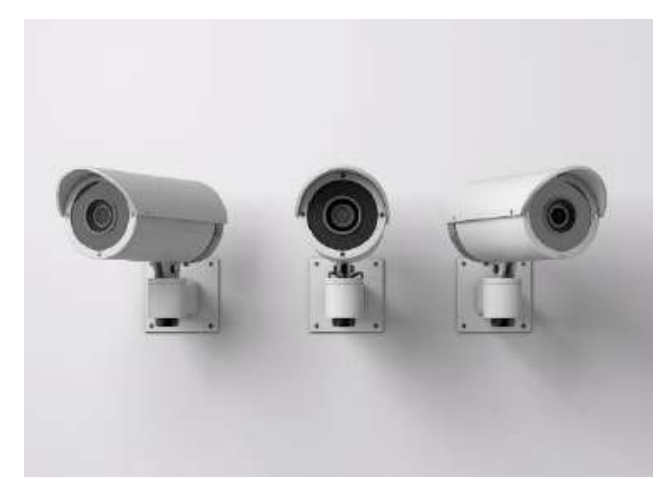


Gambar 25. CCTV/Sistem Keamanan

\section{KESIMPULAN}

Berdasarkan penelitian yang telah dilakukan sesuai data dan fakta lapangan dan proses perancangan sebelumnya yang berprogres, kemudian dilanjutkan ke perancangan dari analisa awal konsep hingga dilanjutkan ke penerapan penerapan desain arsitektur. Perancangan bangunan ini menggunakan pendekatan arsitektur Neo-Vernakular karena menunjukan kesan budaya di lokasi tapak terpilih, yaitu Yogyakarta. Yang mana Kota Yogyakarta merupakan salah satu kota dengan Seni dan Budaya yang masih melekat. Beikut ini merupakan semua hasil dari proses perancangan akhir desain arsitektur Museum dan Galeri Seni di Yogkarta dengan pendekatan arsitektur Neo-Vernakuar.

Meliputi :

1. Gambar Kerja

2. Gambar Perspektif Eksterior

3. Gambar Perspektif Interior

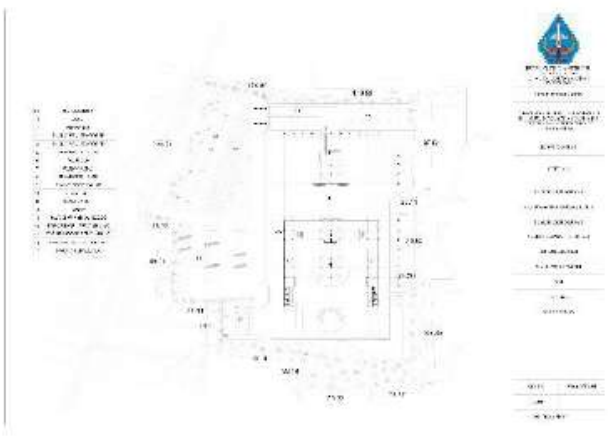

Gambar 26. Denah Siteplan

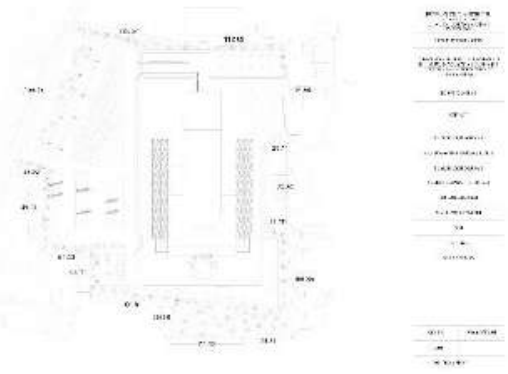

Gambar 27. Denah Situasi

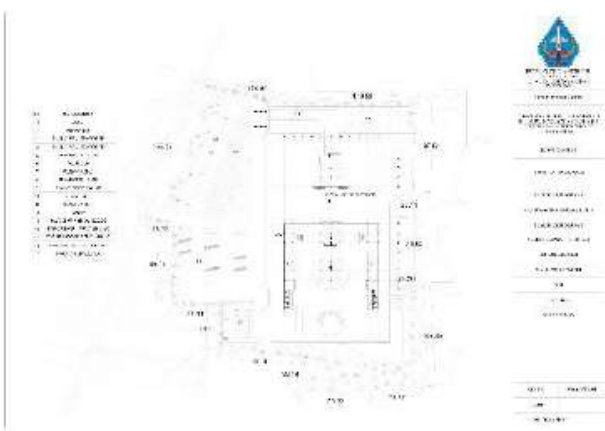

Gambar 28. Sirkulasi Kendaraan

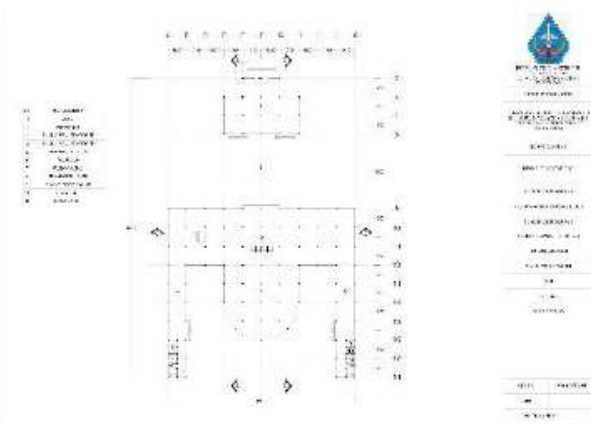

Gambar 29. Denah Ground Floor

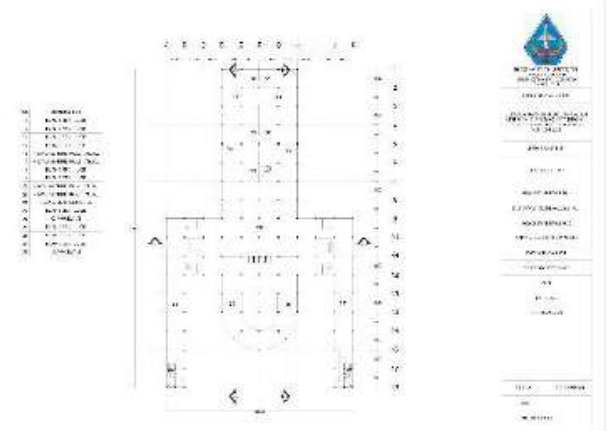

Gambar 30. Denah Lantai 2 

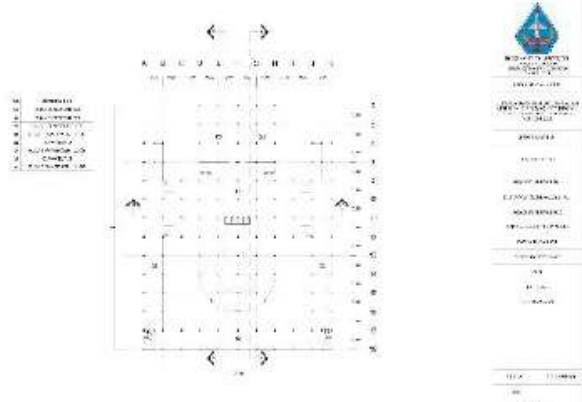

Gambar 31. Denah Lantai 3
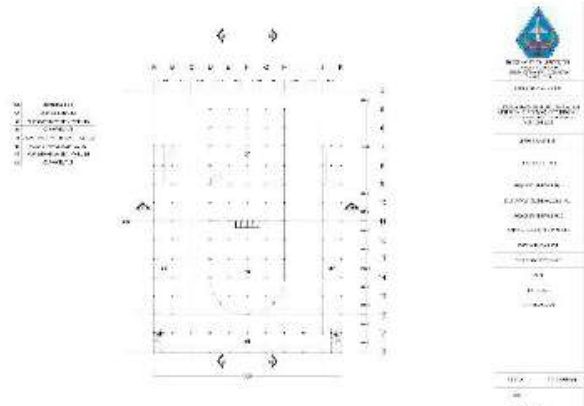

Gambar 32. Denah Lantai 4

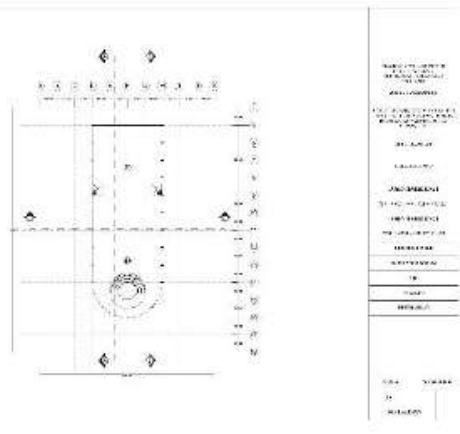

Gambar 33. Denah Rooftop
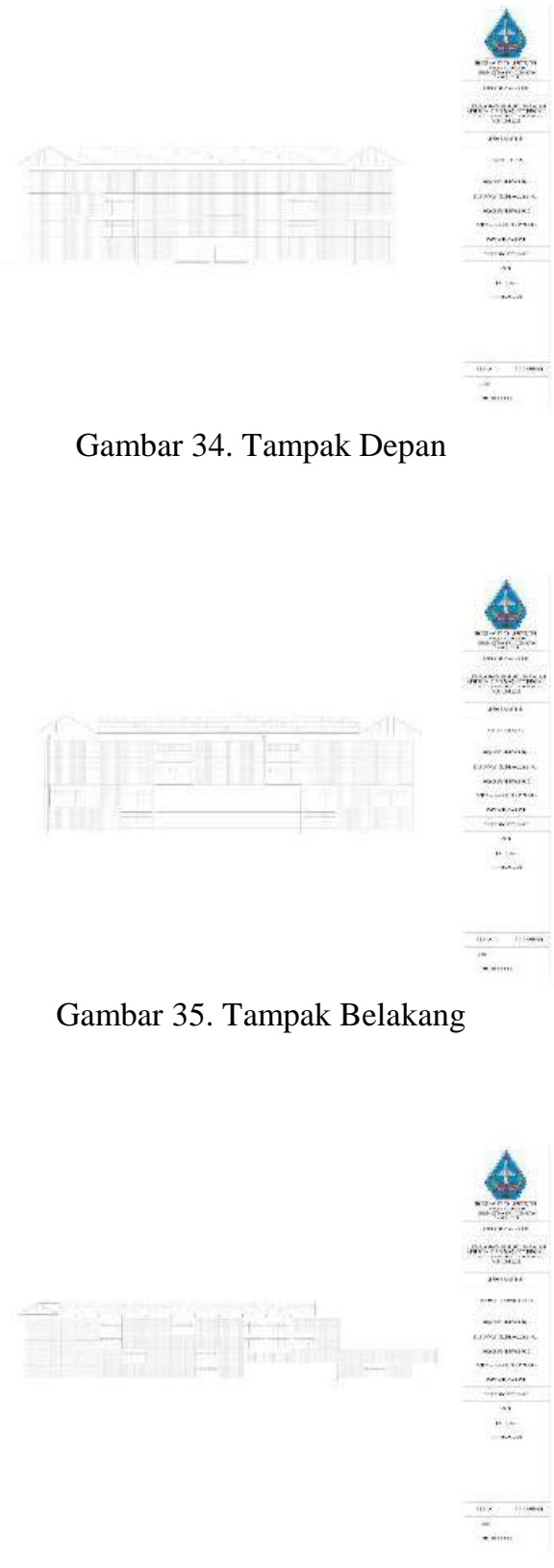

Gambar 36. Tampak Samping Kanan

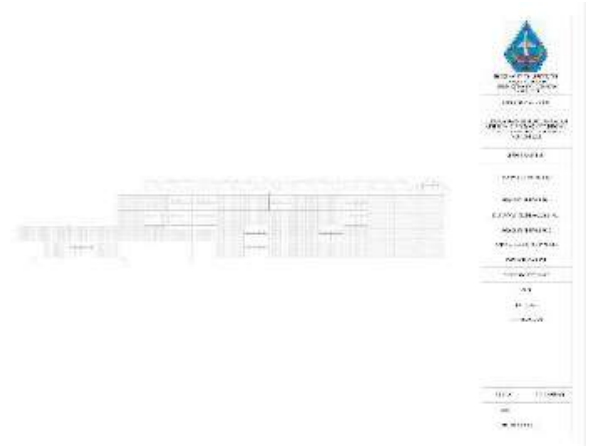


Gambar 37. Tampak Samping Kiri

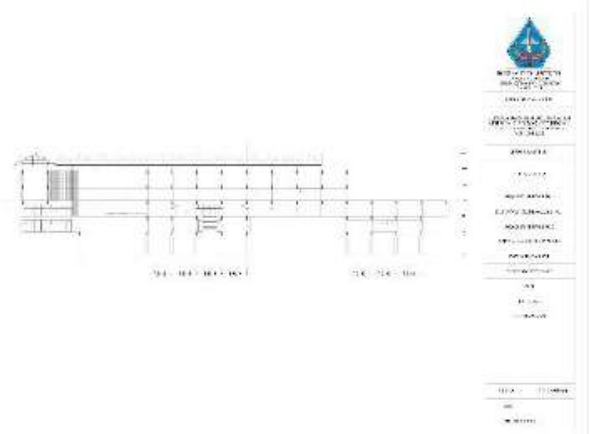

Gambar 38. Potongan A-A

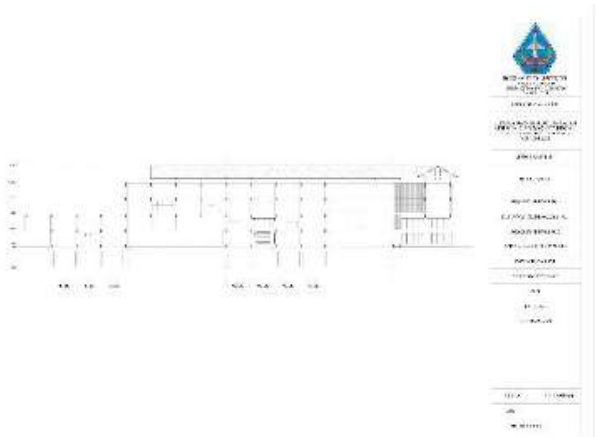

Gambar 39. Potongan B-B
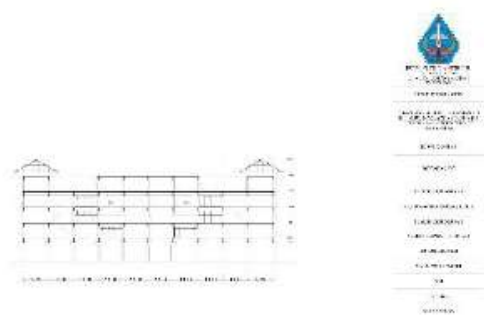

$\because \cdots$

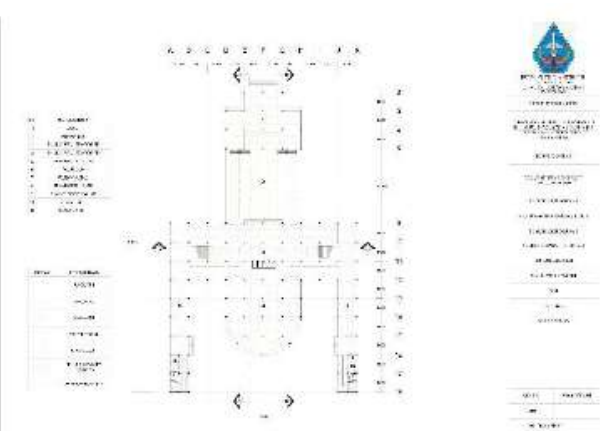

Gambar 41. Denah Peletakan Lampu

Ground Floor

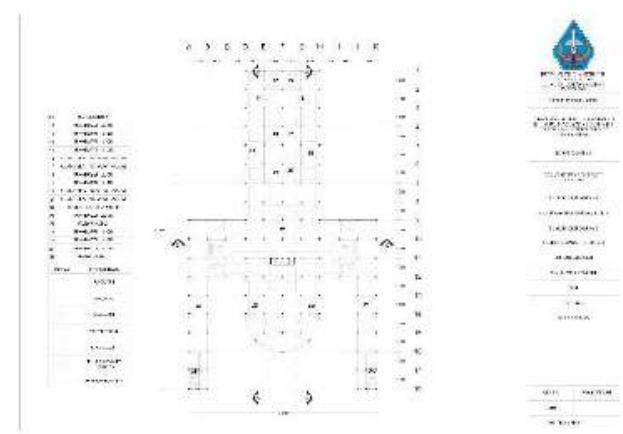

Gambar 42. Denah Peletakan Lampu Lantai 2

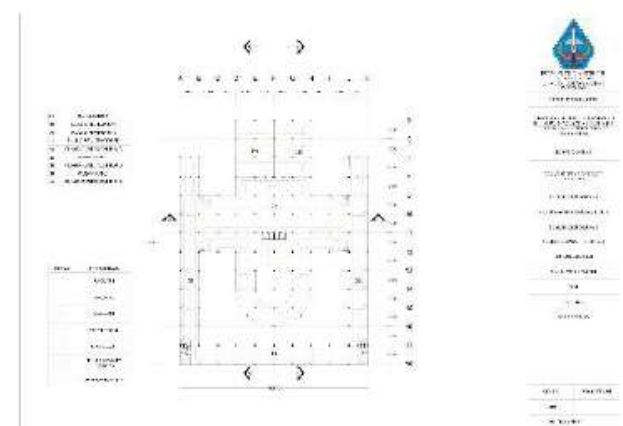

Gambar 43. Denah Peletakan Lampu Lantai 3

Gambar 40. Potongan C-C 


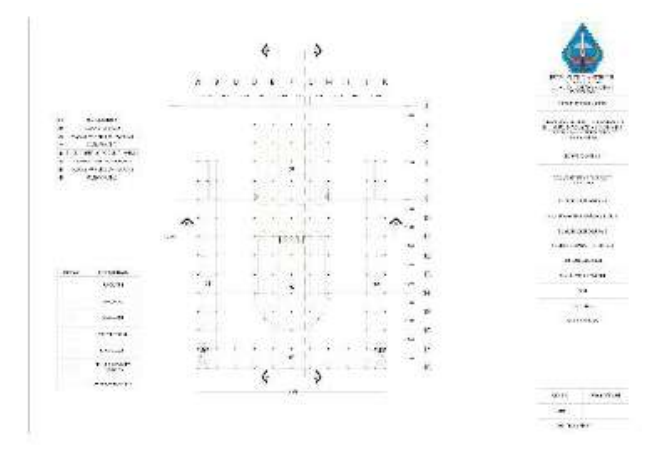

Gambar 44. Denah Peletakan Lampu Lantai 4

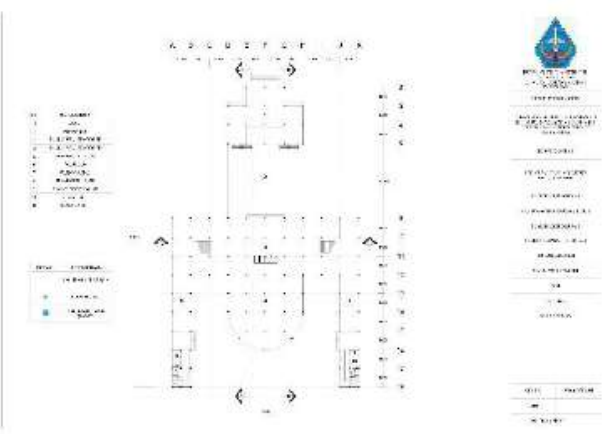

Gambar 45. Denah Saluran Air Bersih Ground Floor

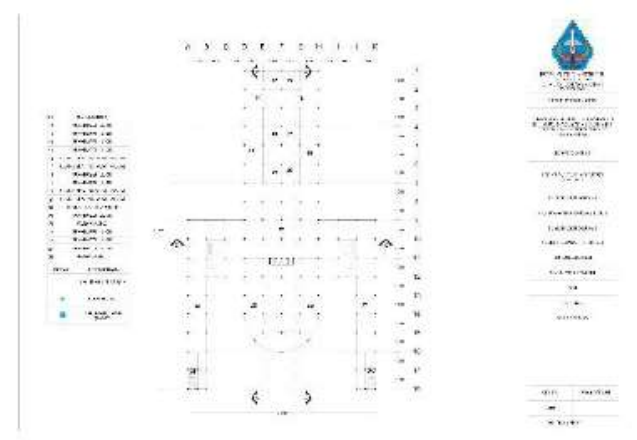

Gambar 46. Denah Saluran Air Bersih Lantai 2

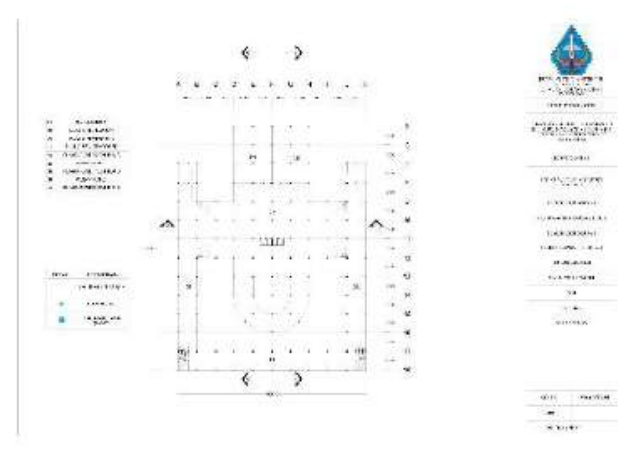

Gambar 47. Denah Saluran Air Bersih Lantai 3

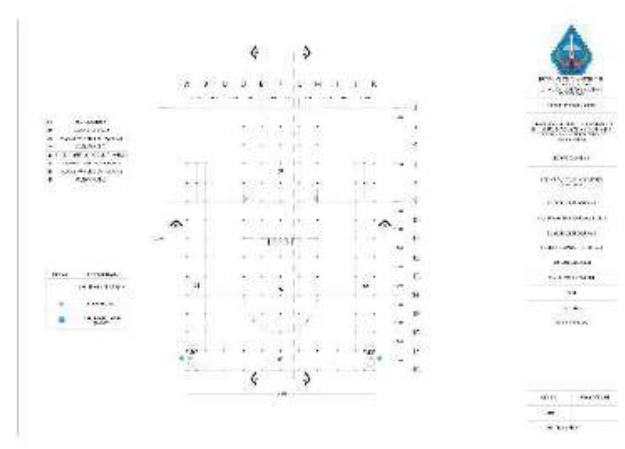

Gambar 48. Denah Saluran Air Bersih

Lantai 4

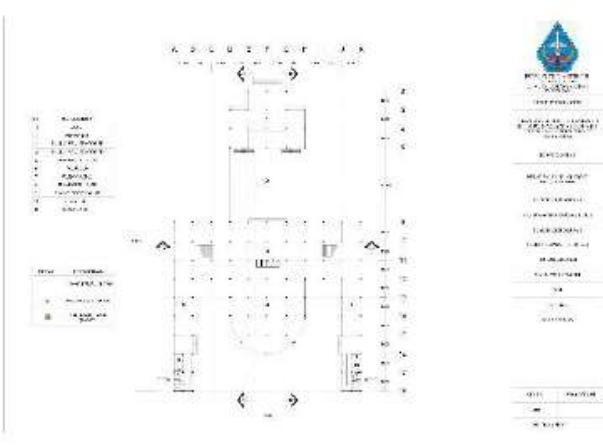

Gambar 49. Denah Saluran Air Kotor Ground Floor 


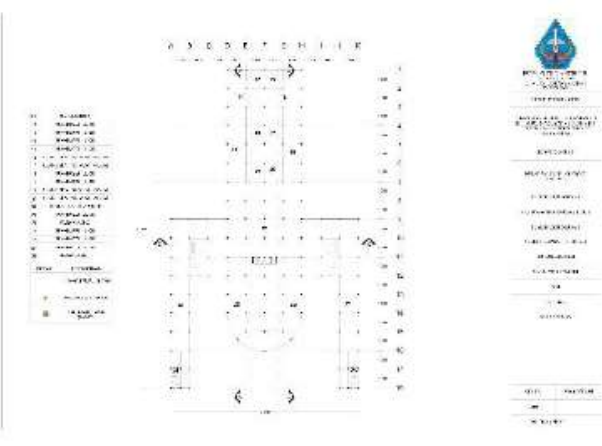

Gambar 50. Denah Saluran Air Kotor Lantai 2

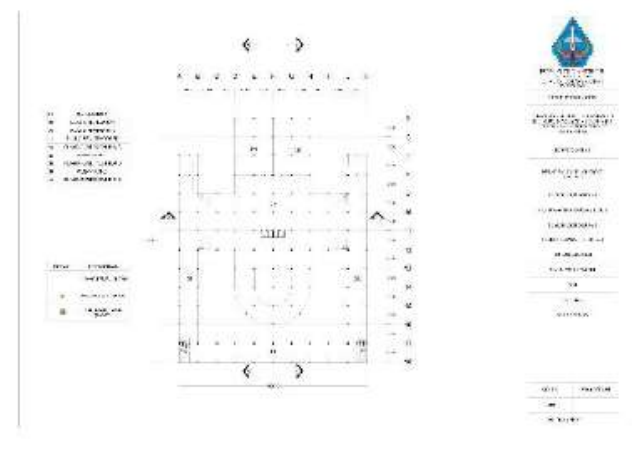

Gambar 51. Denah Saluran Air Kotor Lantai 3

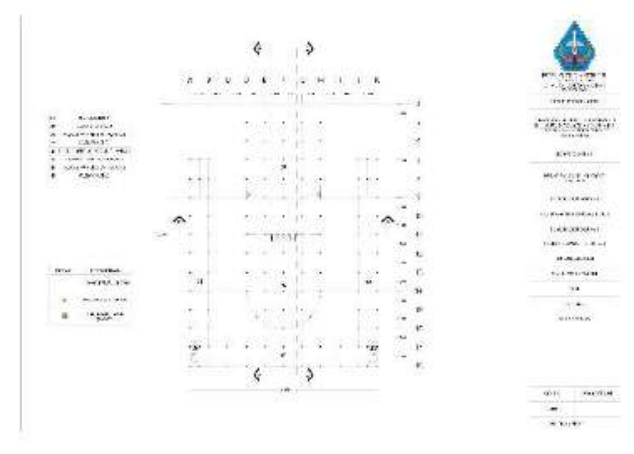

Gambar 52. Denah Saluran Air Kotor Lantai 4

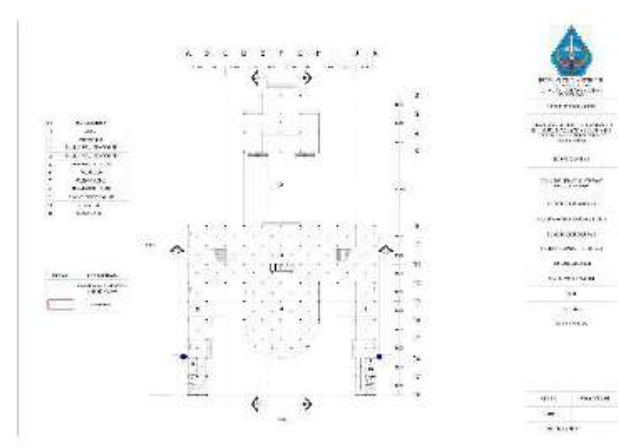

Gambar 53. Denah Peletakan Hydrant Ground Floor

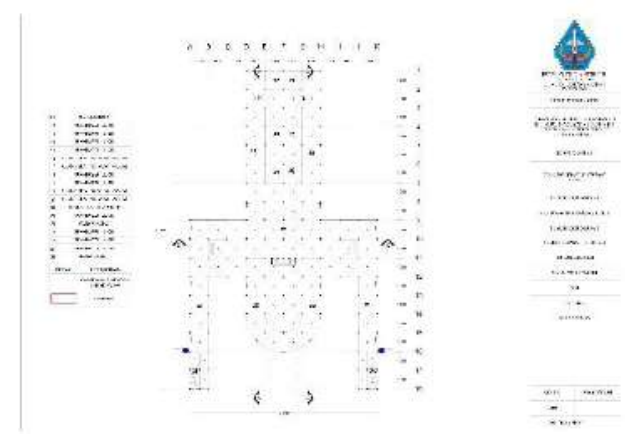

Gambar 54. Denah Peletakan Hydrant Lantai 2

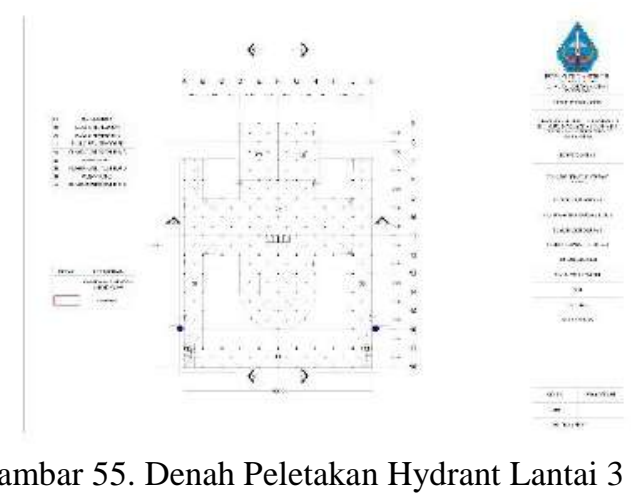

Gambar 55. Denah Peletakan Hydrant Lantai 3 


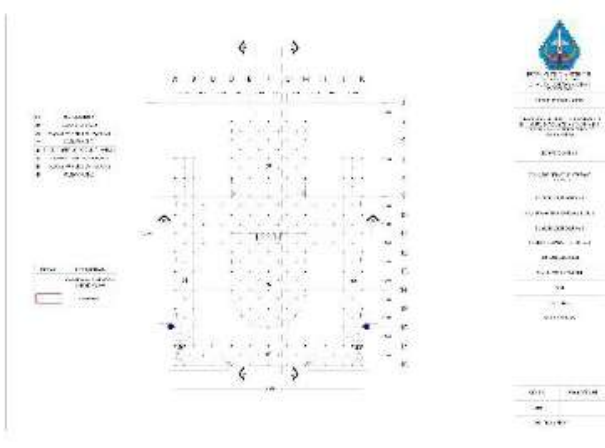

Gambar 56. Denah Peletakan Hydrant Lantai 4

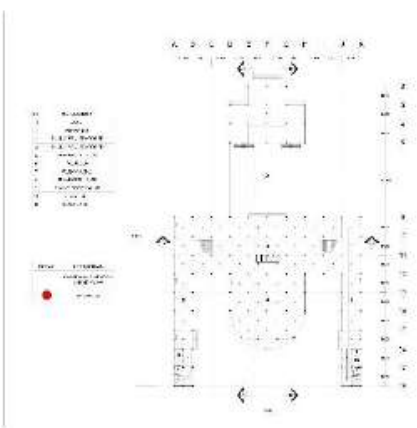

Gambar 57. Denah Peletakan Sprinkler Ground Floor
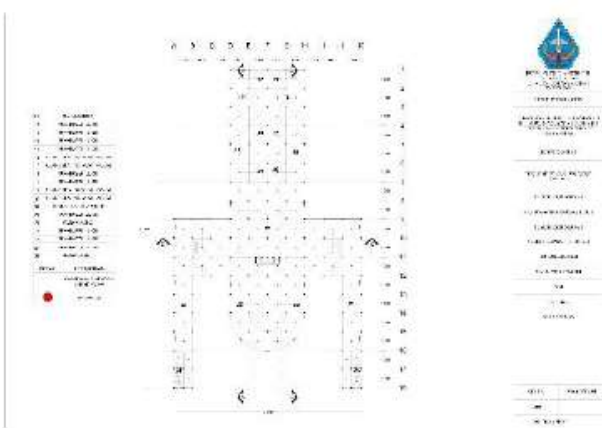

Gambar 58. Denah Peletakan Sprinkler Lantai 2

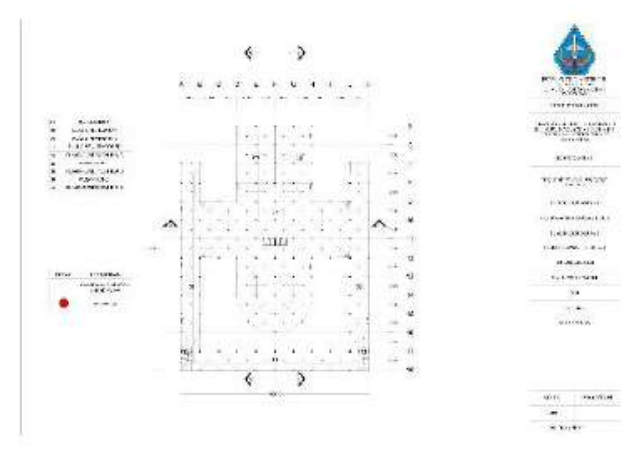

Gambar 59. Denah Peletakan Sprinkler Lantai 3

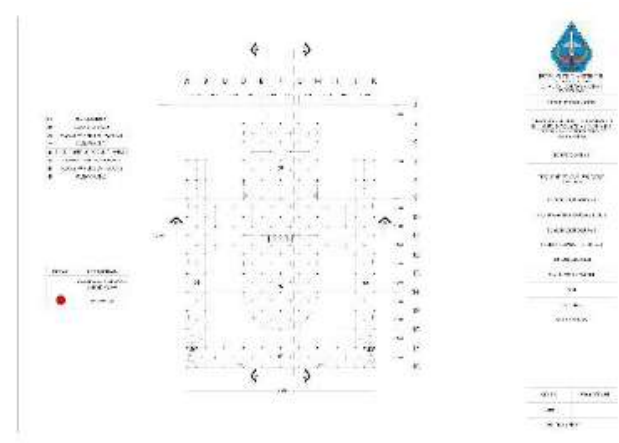

Gambar 60. Denah Peletakan Sprinkler Lantai 4

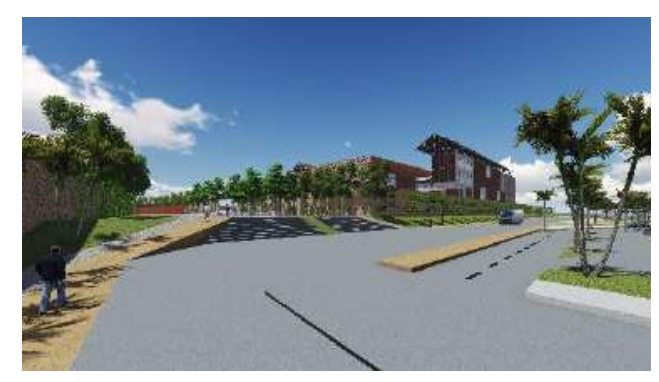

Gambar 61. Perspektif Eksterior

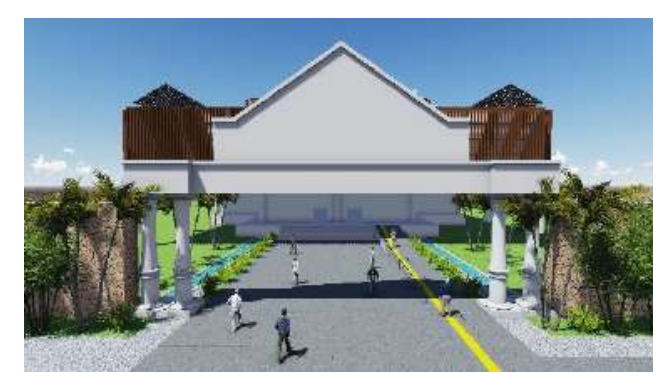

Gambar 62. Perspektif Eksterior 


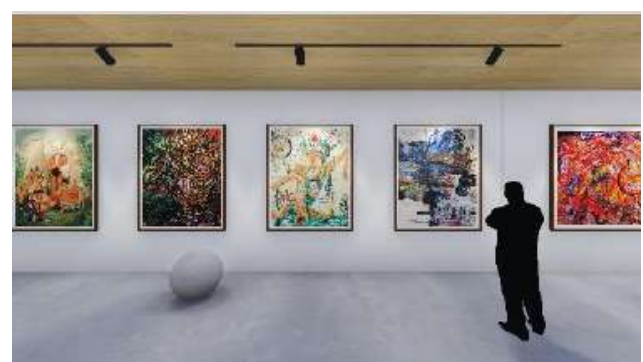

Gambar 63. Perspektif Interior

Ruang Seni Lukis

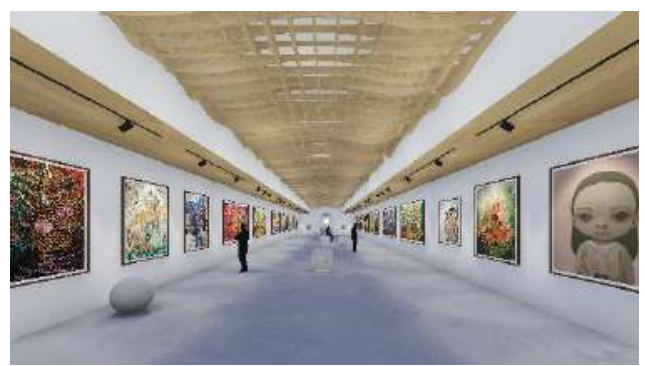

Gambar 64. Perspektif Interior Ruang Seni Lukis

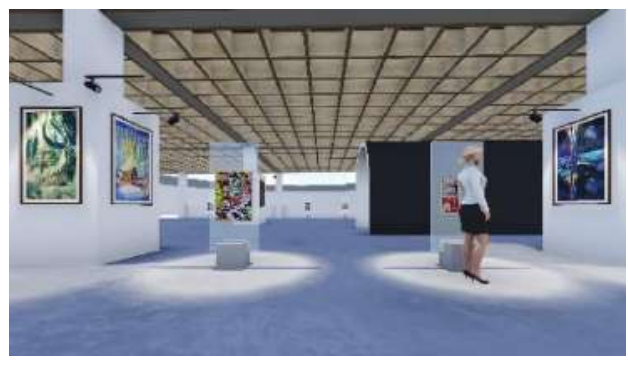

Gambar 65. Perspektif Interior Ruang Seni Lukis Kontemporer

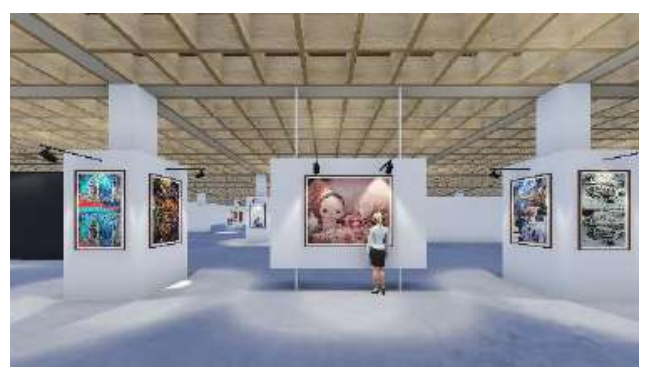

Gambar 66. Perspektif Interior Ruang Seni Lukis Kontemporer

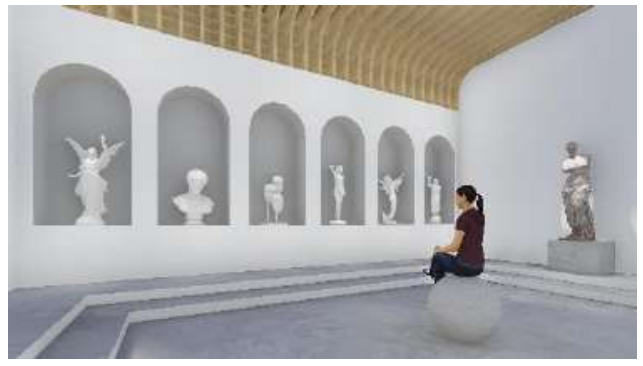

Gambar 67. Perspektif Interior Ruang Seni Patung

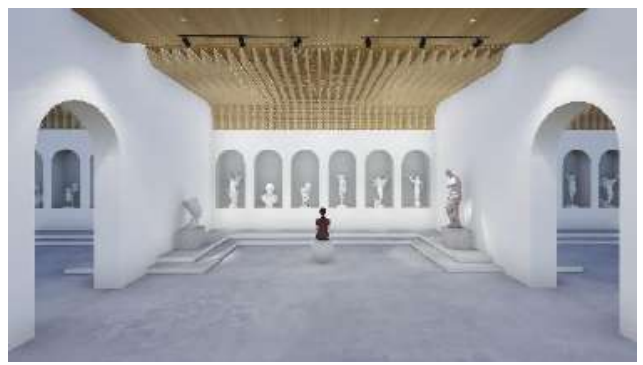

Gambar 68. Perspektif Interior Ruang Seni Patung

\section{DAFTAR PUSTAKA}

Universitas Islam Indonesia (2019). Museum Seni Rupa Modern di Yogyakarta

Ching, Francis D.K (1993). Teori Arsitektur: Ruang, Bentuk dan Susunannya. Jakarta. Erlangga

Abdul Aziz Arsyid, Samsudi, Ummul Mustaqimah (2016). Museum Songket Palembang Dengan Pendekatan Arsitektur NeoVernakular UNS

Heru Budi Kusuma S.Sn,M.Ds (2018). Wayfinding Sign Pada Ruang Pameran Tetap di Museum Nasional Indonesia, Jakarta. Mudra Jurnal Seni Rizki Muhammad (2016). Galeri Seni dan Budaya di Surakarta Dengan Penekatan Desain Green Architecture http://jogjagallery.net/ http:// e-journal.uajy.ac.id/ http:// www.archdaily.com/ 